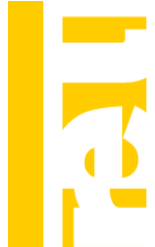

\title{
IS WORKERS' EFFORT SENSITIVE TO CONTRACT TYPE AND FIRM OWNERSHIP? THE SPANISH CASE
}

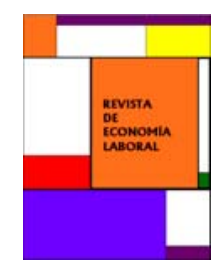

César Rodríguez-Gutiérrez ${ }^{1}$ and Juan Francisco Canal-Domínguez

Universidad de Oviedo

Received 24th September 2010; accepted $7^{\text {th }}$ November 2011

\section{Resumen}

El objetivo de este artículo es conocer si el esfuerzo laboral de los trabajadores españoles es sensible al tipo de contrato y a la propiedad de la empresa (pública o privada). Para ello, se estima una función de esfuerzo laboral en la que esta variable se explica por el salario y por un conjunto de factores que representan las características de los trabajadores, de los empleos y de las empresas. La base de datos utilizada es la "Encuesta de Calidad de Vida en el Trabajo" 1999-2004. Los resultados muestran que el esfuerzo laboral depende positivamente de la predicción salarial. Además, el esfuerzo laboral es mayor en el sector privado que en el público. En este sentido, se ha observado que ser funcionario ejerce un efecto negativo sobre la intensidad del esfuerzo laboral. Finalmente, las variables que representan el clima de relaciones laborales también son muy relevantes en la explicación del esfuerzo.

Palabras clave: Esfuerzo laboral, motivación, salarios.

Clasificación JEL: J24, J41, J45.

\section{Abstract}

The aim of this paper is to know whether labour effort of Spanish workers is sensitive to contract type and firm ownership (public or private). So, a labour effort function is estimated to explain this variable by the wage level and a group of factors representing worker, job and firm features. The database used is the 'Quality of Work Life Survey' 19992004. The outcomes show that labour effort depends positively on the predicted wage. Besides, labour effort is greater in the private sector than in the public one. In this sense, it has been observed that being a civil servant has a negative effect on the intensity of labour effort. Finally, those variables representing the climate of industrial relations are found to be quite relevant.

Key words: Labour effort, Motivation, Wages.

JEL Classification: J24, J41, J45.

${ }^{1}$ Contact author: crodri@uniovi.es . This article has been funded by the Spanish Ministry of Science and Innovation (Project ECO2008-03468).

(C) Revista de Economía Laboral 


\section{Introduction}

It is normally stated that private sector workers show higher levels of productivity and effort when carrying out their tasks than those from the public sector due to different reasons. On the one hand, private firms usually develop incentive plans in which productivity is always awarded with higher wages and some other types of advantages. It would be quite difficult to apply incentive plans to those public sector areas in which workers' labour effort is not easy to be measured. On the other hand, the special labour status of most Spanish workers from the public sector, characterized by great contract stability (for example, absolute employment stability in the case of civil servants - funcionarios), may trigger some unproductive behaviours which will be difficult to correct just by means of penalties or dismissals (something that does not occur with the same intensity in private firms).

At the end of the 90's, a great amount of former public firms were privatized. As a consequence most part of public employment is nowadays to be found in the Public Administration (Local, Regional and State). There are still some public firms whose weight in relation to total employment have been reduced, and most of which are besides no longer managed by the State Government, but by the Autonomous Communities or City Councils (for example, in the case of local and regional television stations, municipal transport companies, etc.). Despite all this, public employment (including different civil services and public firms) remains

relatively important. From the sample used in this paper ('Quality of Work Life Survey'-QWLS), public employment meant approximately 25 per cent of all Spanish employment for the period 1999-2004.

In relation to workers' labour effort measurement, it must be stated that the lack of official statistics on this matter makes it difficult to compare both private and public sectors, so as it will be stated later on, in this case, we create workers' labour effort indicators from the information contained in the QWLS. Moreover, labour effort levels clearly depend on many other factors besides the public or private nature of firms. So, for example, it is considered that workers' effort depends mainly on wages if we take into account the efficiency wage perspective and therefore firms create wage premiums in order to increase workers' efficiency. This behaviour, while increasing firms' profit, may lead to raise unemployment. There are many reasons for workers to react by increasing effort and productivity when receiving higher wages. First, higher wages may prevent workers from shirking (Shapiro and Stiglitz 1984). Second, higher wages may also reduce labour turnover and so, the hiring and training 
costs associated to new workers (Stiglitz 1974). In the third place, higher wages make workers feel fairly treated and motivated to achieve firms' targets (Akerlof 1982). Finally, higher wages make it possible to hire better workers (Weiss 1980).

However, effort level-wages relationship has been traditionally considered the other way round. The basic theory of wage determination in a competitive labour market is the theory of net advantages. According to it, if an individual carried out a task making greater efforts than the others, he should be compensated for this additional effort (compensating wage difference), as, if not, he would resign from his post or would carry out his tasks with the least effort required (Rosen 1986).

To sum up, on the one hand, traditional wage theory states that wages are a function of workers' effort. On the other hand, the efficiency wage theory sets out that workers' effort depends on the wages they get paid. So, it is clear that there is a two-way relationship between both variables. $^{2}$

In order to know the theoretical relation between labour effort and wages, this paper proposes a model in which workers' effort for every possible wage will be the result of an optimizing behaviour of both workers (who maximize their utility) and firms (which maximize profits). In the long-term equilibrium, when all firms have normal profits, the relation between worker's effort intensity and wage earned will be positive. Besides wages, we may identify many other variables affecting workers' labour effort, for example, this paper takes into account different personal worker features as well as certain job and firm features such as private or public ownership. As Spanish public sector normally ensures greater employment stability (little chances of being fired) than the private sector, and as the likelihood of being fired (or the probability of shirking detection) is one of the main determinants of labour effort ${ }^{3}$ according to previous studies, then, it is expected that working in the private sector of the economy would have a clearly stimulating effect on labour effort levels.

Few papers have estimated the effects of labour effort determinants, mainly because there are no accurate databases available which provide information related to the levels of effort reached by workers. One may cite the papers by Fairris and Alston (1994), Goldsmith et al. (2000), Clark and Tomlinson (2001), Brown et al. (2004), Mühlau and Lindemberg (2003), Clark et al. (2010), and for the Spanish case, Jimeno and Toharia (1996). In this sense, it is worth noting that our paper is one of the few attempts to analyse this issue for the Spanish case. The

\footnotetext{
${ }^{2}$ A relevant example of how to join both theories is found in Fairris and Alston (1994).
}

${ }^{3}$ See, for example, Fairris and Alston (1994), p. 151. 
structure of this paper is as follows. In Section 2, we propose a theoretical framework that allows establishing the determinants of worker's labour effort, mainly, the positive relation between the level of effort and wages. In Section 3, we present the estimations of the labour effort function for the total worker sample and for men and women subsamples. Finally, in Section 4 , we present briefly the main conclusions reached.

\section{The Model}

This section proposes a model to determine the long-term equilibrium values for workers' labour effort level. Individuals are assumed to have a utility function that depends positively on the hourly wage, $W$, and negatively on the individual labour effort per hour, $e$.

So, worker's utility function is as follows:

$$
U=U(W, e) ; \quad \frac{\partial U}{\partial W}>0, \quad \frac{\partial U}{\partial e}<0
$$

On the other hand, firm's production function is:

$$
Y=Y(L \cdot e) ; \quad \frac{\partial Y}{\partial L}>0, \quad \frac{\partial Y}{\partial e}>0, \quad \frac{\partial^{2} Y}{\partial e^{2}}<0
$$

where $Y$ is the output, $L$ is the number of working hours and L.e is the total amount of effective work (measure in effort units). Given $L$, output grows as effort intensity, $e$, increases, following the law of decreasing returns. In order to simplify, $L$ is assumed to be the sole input.

Therefore, firm's profit function is:

$$
\pi=P Y(L \cdot e)-W L
$$

where $P$ stands for the output price that is assumed to be given.

In order to simplify, we may assume that the economy is at full employment and all firms have set their long-term employment level. Therefore, firm's optimal employment is pre-determined in the model, and the output will be just a function of the effort required to carry out their tasks during the period workers remain in their workplaces. Then, once the level of employment is determined, firms and workers should set up effort levels and wages. Full employment gives extraordinary bargaining power to workers. They are in the position of setting up both wages and 
effort levels that maximize their utility subject to the restriction of firms having zero profits. Workers achieve this by moving among firms looking for maximizing their net advantages (the model only considers one advantage, $W$, and one disadvantage, $e$ ). Therefore, in a long-term equilibrium, when all the adjustments are completed, firms will not have extraordinary profits and workers will stop moving among different jobs.

So, the problem to be solved is:

$$
\begin{aligned}
& \operatorname{Max}_{W, e} \quad U=U(W, e) \\
& \text { S. } a \quad P Y(L \cdot e)-W L=0
\end{aligned}
$$

The first-order conditions for this maximization problem lead to the following equilibrium equation:

$$
-\frac{U M g_{e}}{U M g_{w}}=\frac{P}{L} \frac{\partial Y}{\partial e}
$$

Graphically, Figure 1 shows the equilibrium solution. To simplify this, we represent a market made up of three individuals $(A, B$ and $C)$ and three firms (1,2 and 3). Each individual has his own preferences in relation to $W$ and $e$. The indifference curves generated by the utility functions have a positive slope. That is, given that effort affects negatively the utility of individuals, in order to keep their level of utility constant, workers will claim to be paid higher wages when making greater efforts to carry out their tasks. Besides, the Marginal Rate of Substitution between effort and wages $\left(M R S=\left.(\Delta W / \Delta e)\right|_{\bar{u}}\right)$ is assumed to be increasing. This means that when workers' effort level is higher, in order to increase marginally their effort, they will demand being compensated with higher wages. Bear in mind that $M R S$ is equal to the first term of the equilibrium condition (5).

As far as firms are concerned, given $P$ and $L$, they are able to achieve long-term profit levels with different combinations of wage level, $W$, and labour effort, $e$. So, it is possible to create an iso-profit curve in the space $(W, e)$, by joining the different combinations of wage level and labour effort that provides firms with the zero profits level. These are the curves $\pi_{0}^{1}, \pi_{0}^{2}$ and $\pi_{0}^{3}$ in Figure 1. Formally:

$$
\pi_{0}=\pi(W, e)
$$


These curves have a positive slope: firms could pay higher wages keeping the same profit levels only if workers increase their labour effort levels. Besides, the Marginal Rate of Technical Substitution between effort and wage level $\left(\operatorname{MRTS}=\left.(\Delta W / \Delta e)\right|_{\bar{\pi}}\right)$ is decreasing. This means that when wage level is getting higher, additional increments of such wage level will require proportionally greater increments of workers' labour effort for firm profits to remain constant. See that MRTS is equal to the second term of the equilibrium condition (5).

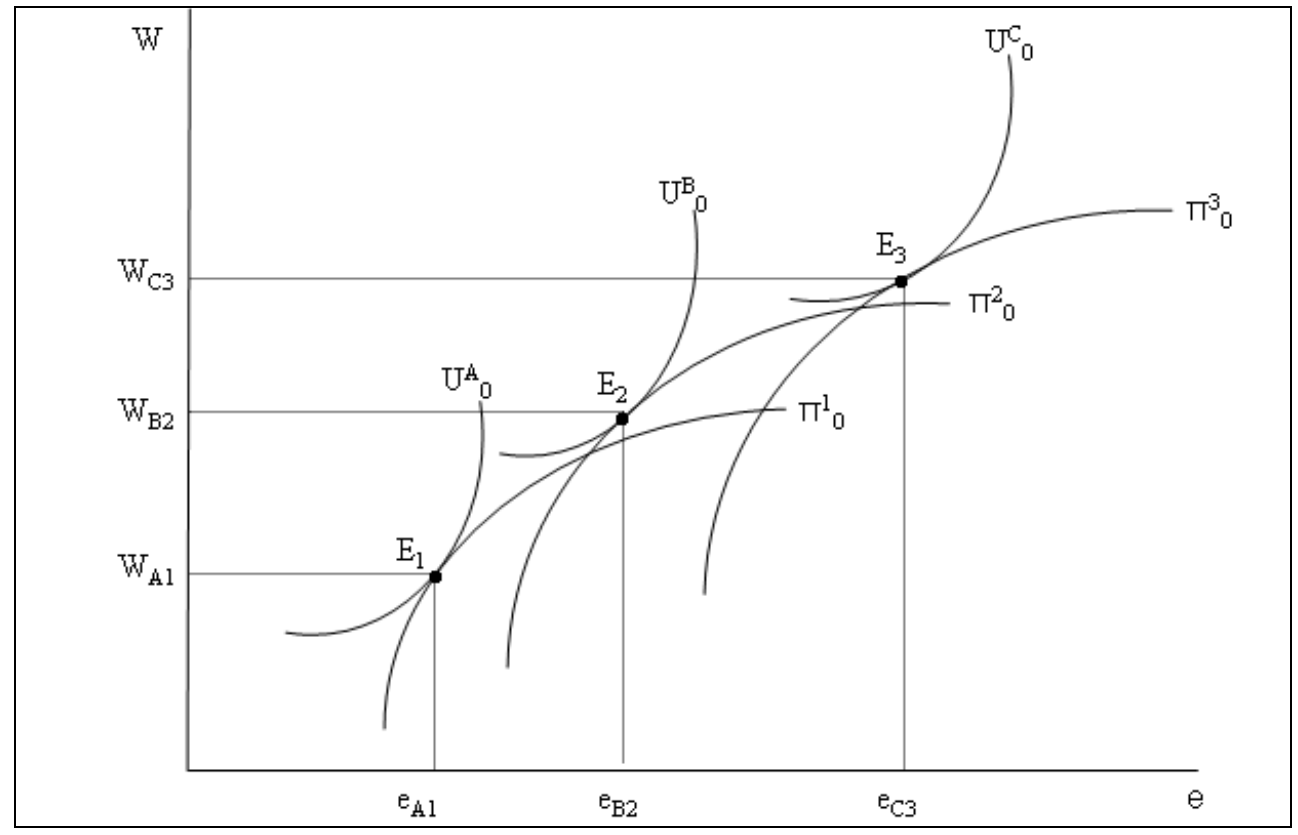

Figure 1: Long-term market equilibrium

Figure 1 shows the long-term equilibrium. The maximization of workers' utility subject to the zero profits restriction for firms, leads to determine the long-term equilibrium values for wages and effort levels. We must bear in mind that in such equilibrium, points $E_{1}, E_{2}$ and $E_{3}$ define the existence of a positive relationship between workers' effort and wage level. But how do things work out in practice? Probably, workers bargain the optimal wage level with the firm and then, they commit themselves to make those efforts needed for firms to have zero profits in 
the long-term. That firm which is ready to pay the highest wages will have workers willing to make the greatest labour effort.

Besides, the effort made for every wage level will depend on several factors that determine the shape and position of the workers' indifference curves and the firms' iso-profit curves. Among the first ones, we include some personal features (for example, variables such as the age, occupation...) that may affect workers' preferences when asking for monetary compensations for different effort levels to be made. Moreover, these preferences may also be influenced by job features (for example, workplace environment).

As far as the iso-profit curves are concerned, their shape may be conditioned by technical features such as firm size. It is also important to note how easy it is for firms to fire workers, that is, the legal framework for adjustment costs. In particular, firms' capacity to stimulate workers' effort by means of higher wages will become more powerful if workers know they can be fired easily when avoiding their duties and obligations (see again Fairris and Alston 1994, p. 151). The likelihood of being dismissed can be proxied by contract type (permanent or fixed-term) and firm ownership (public or private). Whatever the ownership might be, it is assumed that it is always easier to fire a temporary worker than a permanent one, as the adjustment costs are lower for the former. On the other hand, regardless which contract type is, public sector tends to provide workers with more labour stability (and in the case of Spanish civil servants, we may estate that the chances of being fired are almost none).

Summing up, given the previous analysis, the following effort equation is proposed:

$$
e_{i}=X_{i}^{\prime} \beta+\eta_{1} W_{i}+\varepsilon_{i}
$$

Equation (7) states that individual labour effort, $e_{i}$, is explained, first, by a vector of exogenous variables, $X_{i}$, which includes individual, job and firm features. Besides, effort level depends on the wage level, $W_{i}$. As effort and wage level are simultaneously determined, there is a clear problem of endogeneity when estimating equation (7). In order to correct this bias, variable $W_{i}$ will be instrumented by using the predicted values obtained from the estimation of a standard wage equation (equation 8). This equation is:

$$
W_{i}=Z_{i}^{\prime} \lambda+\mu_{i}
$$


where $Z_{i}$ is a vector of exogenous variables also including personal, job and firm features. So, the estimation of the effort equation will be carried out in two steps. In the first stage, we will proceed to estimate equation (8). Then, in a second stage, predictions on wages obtained from equation (8), $\hat{W}_{i}$, will be included in the estimation of the effort equation (7) instead of $W_{i}$. This way of generating wages allows correcting the endogeneity of such variable in the estimation of the effort equation. So, the final equation to be estimated is:

$$
e_{i}=X_{i}^{\prime} \beta+\eta_{1} \hat{W}_{i}+\varepsilon_{i}
$$

\section{Estimations of the effort equation}

\subsection{Data}

This paper uses data taken from the 'Quality of Work Life Survey', carried out by the Spanish Labour and Immigration Ministry for the period 1999-2004. ${ }^{4}$ This survey is not structured as a panel and reports information from 6,000 different individuals every year. The sample used is made of 15,252 wage earners from public and private sectors of the economy. All the variables included in the estimations are defined in Table A. 1 of the Appendix.

In relation to the variable representing individual labour effort, the survey provides an ordinal and subjective measure. It is just the answer to the following question: "How do you agree or disagree with this sentence? I am ready to work more than I should just for the benefit of the firm or organization I am working for." The individual must give an answer within a scale ranging from 1 (strongly disagree) to 5 (strongly agree). We will name this variable labour effort. Although this is clearly a subjective effort measure, we assume that the number (1 to 5 ) stated by the individual regarding his being ready to work more than he should, is directly related to the intensity of efforts made currently at work. These types of subjective indicators are commonly assumed in literature, since authors such as Freeman (1978) and Borjas (1979) turned them popular in their papers on job satisfaction (which was measured in all databases by means of subjective ordinal indexes). Moreover, previous studies normally

\footnotetext{
${ }^{4}$ Complete information on this survey is available at the Ministry of Labour and
} Immmigration web site: www.mtin.es. 
use very similar labour effort indicators, which are multidimensional concepts, as Currie and Steedman (1997) pointed out. So, Mühlau and Lindenberg (2003) and Clark et al. (2010) use exactly the same variable. ${ }^{5}$ On the other hand, Fairris and Alston (1994) include workers' answer to the statement: "My job requires that I work very hard" in order to build a dummy variable taking value 1 if workers do strongly agree or agree with this statement or value 0 if they strongly disagree or disagree with it. ${ }^{6}$ Finally, Clark and Tomlinson (2001) use the answers to the following questions as labour effort indicators: "How much effort do you put into your job beyond what is required?" and "Compared with others how much work do you do?" The first question allows four answers ranging from no effort to a lot of effort, and the second allows for five answers, from much less work to much more. Bear in mind that the first question generates a labour effort indicator very similar to the one used in this paper.

It is interesting to analyse the distribution of the labour effort indicator (Figure 2). For example, in the case of private sector workers, we see that the most frequent effort level takes value 4 (for 28.6 per cent of the individuals); whereas in the public sector the most frequent value is 3 (27.8 per cent of the total subsample). As an average, private sector workers declare an effort level of 2.99 out of 5 , whereas this is 2.84 in the case of public sector workers.

\subsection{Estimations}

Labour effort equation has been estimated for the total sample and for men and women subsamples, given the different behaviour of men and women in the labour market. The interpretation of the results will allow us to know how individual effort responds to changes in their determinants according to gender.

5 Mühlau and Lindenberg (2003) consider that this variable measures workers' commitment to the firm. This is somehow a way of approaching the intensity of the applied effort.

6 Brown et al. (2004) use the answers to a similar question as effort indicator. Alternatively, they use the answers to the following statements: "I feel loyal to my organization" and "I share many values of my organization." 


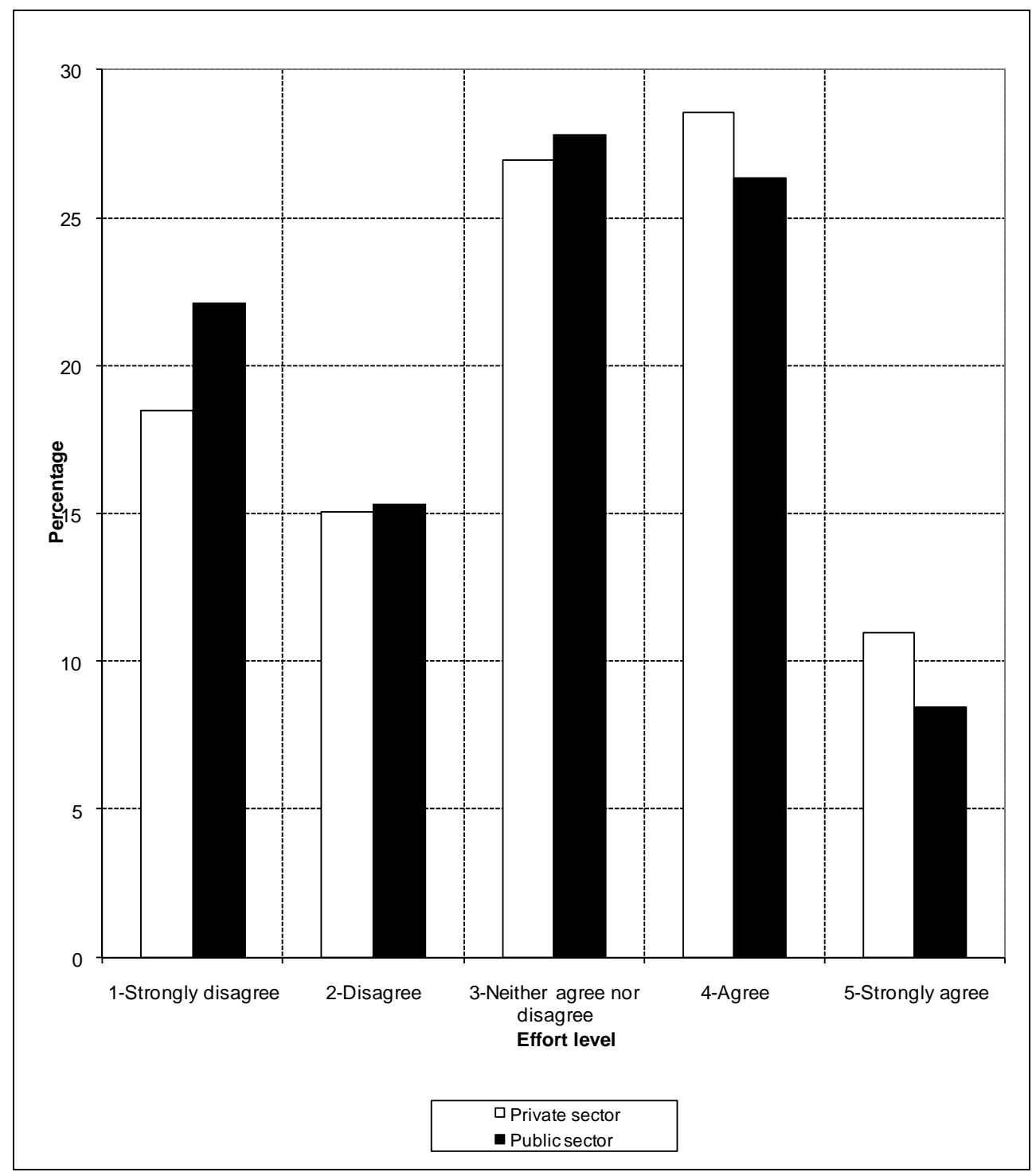

Figure 2: Labour effort level by firm ownership, from 1 to 5 (percentages). "How do you agree or disagree with this sentence? I am ready to work more than I should just for the benefit of the firm or organization"

Table 1 shows the results of the estimations. In a previous stage, we estimated a wage equation in order to calculate the predicted wage, 
which is included in the effort equation as an explanatory variable. The outcomes of the wage equation were fully standard. ${ }^{7}$ As far as model identification is concerned, the independent variables included in the wage equation are those exogenous variables included in the effort equation plus a set of dummy variables representing different levels of education. Ceteris paribus, there are no reasons to assume that educational level will affect either positively or negatively the intensity of workers' labour effort, whereas, as the human capital theory suggests, it is in fact a key determinant for earnings. In this sense, Fairris and Alston (1994) and Brown et al. (2004) do not include educational variables in their labour effort equations. ${ }^{8}$ On the other hand, as the wage variable was originally measured in the Survey by intervals of earnings, in order to estimate the wage equation, we apply the interval regression method.

As labour effort is measured within an ordinal scale ranging from 1 to 5 , in order to estimate the effort equation we use the ordered probit model. ${ }^{9}$ Firstly, estimation outcomes show that the intensity of workers' effort increases as the predicted wage rises. This is a very common outcome found in literature (see, for example, Brown et al. 2004; Clark and Tomlinson 2001; Fairris and Alston 1994; Goldsmith et al. 2000; Mühlau and Lindenberg 2003) and it is aligned with the efficiency wage hypothesis: firms stimulate workers' effort by establishing higher wages. ${ }^{10}$

As far as the effect of workers' features is concerned, we see first that age (which is used as a proxy for labour experience) does not significantly influence labour effort. The effect of this variable is not clear in the literature. For example, Goldsmith et al. (2000) and Jimeno and Toharia (1996) find that labour effort decreases as the age increases; and Clark et al. (2010) detect a significant and positive relation in some cases, whereas, in others, that effect is not significant, depending on how the effort variable is defined.

\footnotetext{
7 Wage equation estimations are not displayed here, but they are available upon request.

8 When educational level variables are included in the effort equation, it is observed that their coefficients are not significant.

9 Following Ferrer-i-Carbonell and Frijters (2004), we proceed to estimate this model taking a cardinal effort variable and using OLS instead of probit models. The outcomes are quite similar to those presented here, which support the authors' suggestion that both methods are valid.

10 Some authors, like Fairris and Alston (1994) and Goldsmith et al. (2000), use wage premium as a dependent variable in effort equations. Wage premium is defined as the difference between the observed wage and the wage that would exist in a competitive labour market.
} 
Table 1: Ordered probit estimates for the effort equation (total sample and men and women subsamples). Dependent variable: Labour effort

\begin{tabular}{|c|c|c|c|c|c|c|}
\hline & Total & & Men & & Women & \\
\hline Independent variables & Coeff. & $z$ & Coeff. & $z$ & Coeff. & $z$ \\
\hline Predicted wage & 0.478 & $3.59^{*}$ & 0.364 & $2.22^{*}$ & 0.501 & $2.49^{*}$ \\
\hline \multicolumn{7}{|l|}{ Worker features } \\
\hline Age & 0.002 & 0.34 & 0.007 & 0.90 & -0.006 & -0.51 \\
\hline $\mathrm{Age}^{2}$ & -0.00004 & -0.47 & -0.0001 & -1.00 & -0.0001 & 0.54 \\
\hline Married & 0.044 & 1.53 & 0.023 & 0.62 & 0.096 & $2.14^{*}$ \\
\hline Separated-Divorced & 0.100 & $2.06^{*}$ & 0.039 & 0.51 & 0.203 & $3.11^{*}$ \\
\hline Widower & -0.040 & -0.52 & -0.269 & $-1.74^{* *}$ & 0.071 & 0.76 \\
\hline Dependent children & -0.073 & $-2.91^{*}$ & -0.014 & -0.44 & -0.181 & $-4.23^{*}$ \\
\hline Union affiliated & -0.089 & $-3.83^{*}$ & -0.097 & $-3.39^{*}$ & -0.080 & $-1.97^{*}$ \\
\hline Born in Spain & -0.135 & $-3.11^{*}$ & -0.058 & -1.09 & -0.281 & $-3.78^{*}$ \\
\hline Male & 0.083 & $2.90^{*}$ & & & & \\
\hline \multicolumn{7}{|l|}{ Job features } \\
\hline Civil servant & -0.257 & $-5.56^{*}$ & -0.185 & $-2.90^{*}$ & -0.302 & $-4.66^{*}$ \\
\hline Permanent labour contract & 0.012 & 0.50 & 0.021 & 0.68 & 0.014 & 0.37 \\
\hline Underemployed & -0.134 & $-5.21^{*}$ & -0.080 & $-2.33^{*}$ & -0.221 & $-5.69^{*}$ \\
\hline Routine job & -0.121 & $-5.55^{*}$ & -0.100 & $-3.75^{*}$ & -0.152 & $-3.92^{*}$ \\
\hline Stressing job & -0.062 & $-3.03^{*}$ & -0.056 & $-2.17^{*}$ & -0.079 & $-2.30 *$ \\
\hline Risky job & -0.053 & $-1.97^{*}$ & -0.044 & -1.49 & -0.166 & $-2.42^{*}$ \\
\hline Tiring job & -0.082 & $-4.40^{*}$ & -0.105 & $-4.51^{*}$ & -0.035 & -1.12 \\
\hline Shift job & -0.055 & $-2.29^{*}$ & -0.057 & $-1.93^{* *}$ & -0.0003 & -0.01 \\
\hline Flexible working hours & 0.213 & $6.91^{*}$ & 0.235 & $6.07^{*}$ & 0.201 & $4.07^{*}$ \\
\hline Promotion prospects & 0.136 & $5.75^{*}$ & 0.147 & $4.94^{*}$ & 0.106 & $2.67^{*}$ \\
\hline Stimulating environment & 0.268 & $13.19^{*}$ & 0.246 & $9.74^{*}$ & 0.314 & $9.13^{*}$ \\
\hline Good work organization & 0.198 & $8.97^{*}$ & 0.189 & $6.79 *$ & 0.218 & $5.92^{*}$ \\
\hline Teamwork & 0.042 & $2.09^{*}$ & 0.071 & $2.85^{*}$ & -0.012 & -0.38 \\
\hline Good labour relations & 0.248 & $11.60^{*}$ & 0.237 & $8.90^{*}$ & 0.250 & $6.87^{*}$ \\
\hline Worker knows firm targets & 0.115 & $5.13^{*}$ & 0.120 & $4.16^{*}$ & 0.119 & $3.27 *$ \\
\hline Worker gives opinions & 0.149 & $7.13^{*}$ & 0.174 & $6.56^{*}$ & 0.134 & $3.97^{*}$ \\
\hline Collective agreement & -0.060 & $-2.42^{*}$ & -0.039 & -1.26 & -0.085 & $-1.97^{*}$ \\
\hline \multicolumn{7}{|l|}{ Firm/Organization features } \\
\hline Public Administration & -0.131 & $-3.04^{*}$ & -0.101 & $-2.21^{*}$ & -0.090 & $-1.68^{* *}$ \\
\hline Public firm & -0.095 & -1.46 & -0.035 & -0.47 & -0.119 & -1.01 \\
\hline Other public organizations & -0.193 & $-2.48^{*}$ & -0.072 & -0.73 & -0.276 & $-2.39^{*}$ \\
\hline Firm/Organization size 1 & 0.368 & $3.76^{*}$ & 0.286 & $2.03^{*}$ & 0.305 & $2.64^{*}$ \\
\hline Firm/Organization size 2-9 & 0.242 & $5.53^{*}$ & 0.207 & $3.51^{*}$ & 0.257 & $3.93^{*}$ \\
\hline Firm/Organization size 10-25 & 0.187 & $4.69^{*}$ & 0.219 & $4.11^{*}$ & 0.106 & $1.78^{* *}$ \\
\hline
\end{tabular}




\begin{tabular}{llllllc}
\hline Firm/Organization size 26-49 & 0.152 & $3.71^{*}$ & 0.153 & $2.88^{*}$ & 0.144 & $2.29^{*}$ \\
Firm/Organization size 50-99 & 0.055 & 1.34 & 0.069 & 1.31 & 0.053 & 0.81 \\
Firm/Organization size 100-249 & 0.090 & $2.28^{*}$ & 0.115 & $2.31^{*}$ & 0.069 & 1.09 \\
Firm/Organization size 250-499 & 0.109 & $2.38^{*}$ & 0.136 & $2.40^{*}$ & 0.100 & 1.28 \\
Firm/Organization size 500-999 & 0.108 & $2.19^{*}$ & 0.137 & $2.14^{*}$ & 0.066 & 0.84 \\
Firm/Org. size is not declared & 0.111 & $2.59^{*}$ & 0.155 & $2.65^{*}$ & 0.036 & 0.56 \\
\hline Estimates include a set of control variables for region, occupation and year & & \\
\hline${ }_{1}$ & 0.210 & 0.98 & 0.117 & 0.51 & -0.237 & -0.77 \\
$\tau_{2}$ & 0.726 & $3.37^{*}$ & 0.655 & $2.83^{*}$ & 0.248 & 0.81 \\
$\tau_{3}$ & 1.507 & $7.02^{*}$ & 1.444 & $6.23^{*}$ & 1.022 & $3.32^{*}$ \\
$\tau_{4}$ & 2.578 & $11.99^{*}$ & 2.530 & $10.90^{*}$ & 2.069 & $6.70^{*}$ \\
\hline Log-likelihood & \multicolumn{7}{c}{$-14,074.02$} & \multicolumn{2}{c}{$-8,065.95$} \\
\hline No. of observations & \multicolumn{7}{c}{9,666} \\
\hline
\end{tabular}

(*) Significant at $5 \%$ level; (**) Significant at $10 \%$ level

In the second place, in the case of women, labour effort significantly increases for married or separated-divorced women (the reference category is single), and decreases when they have dependent children. The higher effort level of married women (also found in Clark et al. 2010; Fairris and Alston 1994; Goldsmith et al. 2000) could be explained by their greater family responsibilities that lead them to work harder. Besides, Goldsmith et al. (2000) consider that married people benefit from great social support which also contributes to a greater motivation. On the other hand, having dependent children significantly reduces woman's labour effort. This is so because in Spain women devote more time than men to household work and children care. The great intensity of household work for women could negatively affect the intensity of their effort in the labour market.

In the third place, estimations show that being a trade union member has a negative effect on labour effort. Clark and Tomlinson (2001) obtain the same result. Brown et al. (2004) also estimate the same effect on workers' level of commitment; although they see that affiliated workers shirk less than non-union employees. However, Goldsmith et al. (2000) state that union affiliation has no effect on labour effort. As Brown et al. (2004) and Green and McIntosh (1998) point out, that membership's negative effect on labour effort or commitment could be explained by the fact that union members feel a stronger sense of security at work. This reduces their chances of being fired, and so, it might discourage them from making efforts. Clark and Tomlinson (2001) state that unions normally bargain better labour conditions (jobs demanding lesser effort intensity) for affiliated workers at those firms where unions negotiate collective 
agreements. Nevertheless, these explanations are not valid for the Spanish case, where affiliated workers have the same labour stability than the others, and our institutional framework makes collective bargaining cover every worker under its scope regardless workers' union affiliation or not. ${ }^{11}$ In our case, the negative effect of union affiliation on labour effort could be caused by a greater demanding activity developed by union members.

In the fourth place, being Spanish (non-immigrant) has a negative effect on the intensity of labour effort as for the woman case. This might be caused by immigrants' higher probability of becoming unemployed due to their labour contracts being temporary and their low bargaining power, especially in the case of female immigrants, which leads them to work harder than the native ones to keep their jobs.

Finally, labour effort is greater in men than in women. This result is not always present in the literature. So, while Goldsmith et al. (2000) and Jimeno and Toharia (1996) find this effect, Clark and Tomlinson (2001) and Brown et al. (2004) see lower effort levels in men, and Clark et al. (2010) obtain either positive or negative signs for this variable depending on the variable used for measuring the effort levels. In the Spanish case, this result may be explained by the fact that in many family units men are still the main income earner. So, within the context of the family labour supply, men are more willing than women to undertake more working hours and more intensive tasks.

As for the variables measuring job features, the results show that their effects on labour performance are very significant. Special attention should be paid to the set of variables measuring labour contract type. The estimation takes into account three contract types: civil servant, only possible for the Public Administration; permanent labour contract, which is common in both private and public sectors (including the Public Administration); and temporary or fixed-term labour contract, which is the least frequent in all sectors (see Table A.2 of Appendix). Surprisingly, having a permanent contract does not have a significant effect on labour effort in relation to the reference category (having a temporary contract). This should not be the expected result, as the greater stability of workers with permanent contracts would imply little chances of being dismissed, which should lead to a lower labour effort according to the shirking model. In fact, this is what Brown et al. (2004), and Jimeno and Toharia (1996) observed. ${ }^{12}$ However, being a civil servant significantly reduces workers'

\footnotetext{
${ }^{11}$ In relation to the features of our bargaining model, see Canal and Rodríguez (2004).

${ }_{12}$ In their paper, Jimeno and Toharia use a different data set (Labour Force Survey) and a different way to proxy labour effort. Concretely, they define a dummy variable
} 
labour effort. So, it seems that this total job security guaranteed to civil servants in Spain (probability of been dismissed close to zero) discourages workers' labour effort in the Public Administration, and it might be one of the main reasons for the differences in labour effort between public and private sectors observed in Figure 2.

In the second place, to be underemployed (having greater skill levels than those required for the position) significantly reduces worker's labour effort, due to a lower motivation. Regarding other job characteristics, having a stressing and routine job contributes to diminish labour effort for both genders. However, having a tiring or shift job is only significant for men whereas having a risky job is only significant for women.

On the other hand, labour effort increases when workers have flexible working hours, there are professional career and promotion prospects, workplace environment is stimulating, job is well-organized, tasks are carried out in groups (except for women), there are good relations and communication channels with the managing board, workers know firm targets and they may give opinions on their tasks. Finally, being covered by a collective agreement has the same negative effect on labour effort than being a trade union member, but only in the case of women and for the total sample. It must be pointed out that being affiliated and being covered by a collective agreement are not equivalent statuses in Spain. Our institutional framework guarantees that most of workers (80 per cent) are covered by some type of collective agreement while only a little amount of them (around 20 per cent) are affiliated (see again, Canal and Rodríguez 2004).

In relation to firm/organization features, the survey information allows us to divide public sector firms and organizations into three groups: Public Administration, public firms and other public organizations. We include these three variables in the estimation, being private firm the reference category. The outcomes show that having a job in the Public Administration has a significant and negative effect on individuals' labour effort for both genders and for the total sample. Besides, having a job in other public organizations has the same effect for the women and the total sample. However, belonging to a public firm has not a significant effect on effort. One of the main features of being employed by the Spanish Public

that takes value 1 if worker is absent from work because of sickness and absenteeism. However, the apparently anomalous result obtained in our paper may be because of Act 45/2002, which introduced the so-called "express firing". Since then, dismissal in Spain is free presented as unfair (improcedente) dismissal, although it has an economic cost. This means that having a permanent contract is not really a guarantee of job stability. 
Administration is labour stability, especially in the case of civil servants whose effect has already been taken into account. Therefore, the significant effect of the Public Administration variable may only be explained by the very special labour conditions stated in such organizations. Probably, these organizations are not directed to efficiency, due to bad working habits and political influences. The combined effect of being civil servant and belonging to the Public Administration provides workers with an extraordinary labour stability and control over their workplaces which yields lower effort levels comparing with private sector workers.

Finally, Table 1 indicates that labour effort is greater in firms/organizations with less than 50 workers (the reference category is firm/organization size $\geq 1000$ ), maybe because the smaller the company, the easier for the employer to control workers' performance and to punish shirking behaviour by firing workers.

The quality of these outcomes may be affected by the existence of a possible self-selection bias because the used sample includes both public and private workers and specially civil servants. In order to become a civil servant in Spain, candidates must pass a public exam (oposición). If those candidates to become civil servants are not a random sample of all workers, then a self-selection problem may come up. To avoid this problem, we proceed to estimate the model excluding the group of civil servants. In that case, the size of the total sample ranges from 15,252 to 13,233 workers, decreasing in 2,019 individuals (1,098 men and 921 women).

Estimation outcomes are shown in Table 2. It can be observed that coefficients are quite similar than those shown in Table 1. The main difference is the lack of significance of Public Administration and other public organizations variables for the women sample. Therefore, if female civil servants are excluded, having a job in the Public Administration or in other public organizations does not lead to a lesser effort of women, compared with those working at private firms. So, female civil servants may be a group of workers with differentiating characteristics. In that sense, Pfeiffer (2011) observes that risk-averse people have a preference for public-sector employment. What is not clear is why risk-aversion could affect work effort in the case of women. Probably, men might develop a professional career in the Public Administration with fewer obstacles than women, which may discourage some women and may help to decrease their motivation to work. In any case, these results state the need of future research in this field. 
Table 2: Ordered probit estimates for the effort equation (total sample and men and women subsamples excluding civil servants). Dependent variable: Labour effort

\begin{tabular}{|c|c|c|c|c|c|c|}
\hline & Total & & Men & & Women & \\
\hline Independent variables & Coeff. & $z$ & Coeff. & $z$ & Coeff. & $z$ \\
\hline Predicted wage & 0.458 & $3.06^{*}$ & 0.451 & $2.27^{*}$ & 0.400 & $1.71^{* * *}$ \\
\hline \multicolumn{7}{|l|}{ Worker features } \\
\hline Age & 0.005 & 0.67 & 0.008 & 0.87 & 0.0001 & 0.01 \\
\hline $\mathrm{Age}^{2}$ & -0.0001 & -0.78 & -0.0001 & -1.02 & 0.00001 & 0.09 \\
\hline Married & 0.060 & $1.95^{* *}$ & 0.024 & 0.59 & 0.129 & $2.64^{*}$ \\
\hline Separated-Divorced & 0.093 & $1.77^{* *}$ & 0.001 & 0.02 & 0.221 & $3.13^{*}$ \\
\hline Widower & 0.00001 & 0.00 & -0.244 & -1.39 & 0.128 & 1.19 \\
\hline Dependent children & -0.081 & $-2.98^{*}$ & -0.023 & -0.68 & -0.198 & $-4.20^{*}$ \\
\hline Union affiliated & -0.118 & $-4.43^{*}$ & -0.116 & $-3.58^{*}$ & -0.122 & $-2.56^{*}$ \\
\hline Born in Spain & -0.134 & $-3.00^{*}$ & -0.071 & -1.30 & -0.257 & $-3.28^{*}$ \\
\hline Male & 0.064 & $1.96^{*}$ & & & & \\
\hline \multicolumn{7}{|l|}{ Job features } \\
\hline Permanent labour contract & 0.015 & 0.63 & 0.013 & 0.42 & 0.012 & 0.32 \\
\hline Underemployed & -0.140 & $-5.20^{*}$ & -0.089 & $-2.44^{*}$ & -0.219 & $-5.32^{*}$ \\
\hline Routine job & -0.110 & $-4.67^{*}$ & -0.087 & $-3.07 *$ & -0.150 & $-3.46^{*}$ \\
\hline Stressing job & -0.077 & $-3.49 *$ & -0.049 & $-1.79^{* *}$ & -0.124 & $-3.25^{*}$ \\
\hline Risky job & -0.068 & $-2.43^{*}$ & -0.060 & $-1.90^{* *}$ & -0.172 & $-2.36^{*}$ \\
\hline Tiring job & -0.093 & $-4.67^{*}$ & -0.103 & $-4.17^{*}$ & -0.067 & $-1.95^{* *}$ \\
\hline Shift job & -0.034 & -1.37 & -0.053 & $-1.69^{* *}$ & -0.001 & -0.02 \\
\hline Flexible working hours & 0.238 & $7.15^{*}$ & 0.251 & $5.90^{*}$ & 0.220 & $4.00^{*}$ \\
\hline Promotion prospects & 0.140 & $5.36^{*}$ & 0.142 & $4.41^{*}$ & 0.131 & $2.91^{*}$ \\
\hline Stimulating environment & 0.277 & $12.64^{*}$ & 0.258 & $9.60^{*}$ & 0.318 & $8.32^{*}$ \\
\hline Good work organization & 0.193 & $7.98^{*}$ & 0.187 & $6.15^{*}$ & 0.211 & $5.14^{*}$ \\
\hline Teamwork & 0.037 & $1.78^{* *}$ & 0.056 & $2.08^{*}$ & 0.012 & 0.34 \\
\hline Good labour relations & 0.257 & $11.22^{*}$ & 0.242 & $8.53^{*}$ & 0.282 & $7.12^{*}$ \\
\hline Worker knows firm targets & 0.127 & $5.35^{*}$ & 0.129 & $4.19 *$ & 0.131 & $3.43^{*}$ \\
\hline Worker gives opinions & 0.151 & $6.78^{*}$ & 0.167 & $5.87^{*}$ & 0.134 & $3.64^{*}$ \\
\hline Collective agreement & -0.063 & $-2.42^{*}$ & -0.053 & $-1.66^{\star *}$ & -0.069 & -1.52 \\
\hline \multicolumn{7}{|l|}{ Firm/Organization features } \\
\hline Public Administration & -0.098 & $-2.77^{*}$ & -0.128 & $-2.64^{*}$ & -0.057 & -0.96 \\
\hline Public firm & -0.099 & -1.36 & -0.071 & -0.86 & -0.165 & -1.11 \\
\hline Other public organizations & -0.030 & -0.32 & 0.061 & 0.51 & -0.144 & -1.00 \\
\hline Firm/Organization size 1 & 0.370 & $3.86^{*}$ & 0.353 & $2.31^{*}$ & 0.348 & $2.75^{*}$ \\
\hline Firm/Organization size 2-9 & 0.284 & $5.33^{*}$ & 0.256 & $3.50^{*}$ & 0.311 & $3.96^{*}$ \\
\hline Firm/Organization size 10-25 & 0.250 & $5.18^{*}$ & 0.268 & $4.06^{*}$ & 0.197 & $2.72^{*}$ \\
\hline Firm/Organization size 26-49 & 0.225 & $4.54^{*}$ & 0.207 & $3.15^{*}$ & 0.244 & $3.22^{*}$ \\
\hline
\end{tabular}




\begin{tabular}{lcccccc}
\hline Firm/Organization size 50-99 & 0.096 & $1.99^{*}$ & 0.085 & 1.33 & 0.128 & $1.65^{* *}$ \\
Firm/Organization size 100-249 & 0.153 & $3.32^{*}$ & 0.151 & $2.58^{*}$ & 0.142 & $1.89^{* *}$ \\
Firm/Organization size 250-499 & 0.151 & $2.92^{*}$ & 0.165 & $2.59^{*}$ & 0.112 & 1.23 \\
Firm/Organization size 500-999 & 0.137 & $2.45^{*}$ & 0.148 & $2.07^{*}$ & 0.107 & 1.19 \\
Firm/Org. size is not declared & 0.167 & $3.13^{*}$ & 0.211 & $2.86^{*}$ & 0.100 & 1.28 \\
\hline Estimates include a set of control variables for region, occupation and year & & & \\
\hline${ }_{1}$ & 0.177 & 0.93 & 0.225 & 0.86 & -0.083 & -0.26 \\
$\tau_{2}$ & 0.700 & $3.65^{*}$ & 0.770 & $2.94^{*}$ & 0.406 & 1.25 \\
$\tau_{3}$ & 1.488 & $7.79^{*}$ & 1.567 & $5.98^{*}$ & 1.186 & $3.64^{*}$ \\
$\tau_{4}$ & 2.560 & $13.33^{*}$ & 2.653 & $10.11^{*}$ & 2.241 & $6.85^{*}$ \\
\hline Log-likelihood & \multicolumn{7}{c}{$-19,177.08$} & $-12,425.50$ & $-6,701.93$ \\
\hline No. of observations & \multicolumn{7}{c}{8,568} & \multicolumn{2}{c}{4,665} \\
\hline
\end{tabular}

(*) Significant at $5 \%$ level; $(* *)$ Significant at $10 \%$ level

\section{Conclusions}

It has been traditionally believed that public sector workers carry out their tasks making less labour effort than private sector workers. The efficiency wage theory suggests that the most relevant variables, when explaining labour effort, are the wages paid to workers and the likelihood of being fired. So, the intensity of labour effort increases as the worker receives higher wages and when his chances of being fired are greater. Therefore, public sector difficulties to apply a wage policy directed to reward workers' effort, together with greater stability of labour contracts for such sector, may be the main reasons for workers' lower labour effort.

In this framework, the aim of this paper is to analyse differences in the intensity of workers' labour effort between public and private sectors by estimating an effort equation. This equation explains differences in labour effort by means of predicted wages and by a wide range of factors including individual, job and firm features, paying special attention to whether labour contracts are permanent or not.

The most relevant results coming from the estimations are as follows. In the first place, following the efficiency wage theory, labour effort increases with predicted wages for the whole sample of workers and for the subsamples of men and women.

In the second place, labour effort is greater in men than in women, partly because men devote less time to household work and dependent people care than women. This allows them to concentrate themselves on their professional career exclusively. In fact, it has been observed that 
having dependent children reduces very much women's labour effort but it does not affect men.

In the third place, having a permanent contract (versus being a temporary worker) does not have any effect on labour effort, maybe because having a permanent contract is not a real guarantee of labour stability nowadays. However, being a civil servant, which in Spain means a full guarantee of labour stability, yields lower effort intensity as expected.

In the fourth place, and partly related to what has been said before, working for the Public Administration has a negative and very significant effect on individual's labour effort. This can be basically explained by the particular labour relations framework present in the Public Administration (in these organizations, hierarchical relations are not as clearly defined as in private firms) and by the lack of suitable control and supervision mechanisms. However, when the group of civil servants is excluded from the sample, as to avoid a possible self-selection bias, the Public Administration variable becomes non-significant for the sample of women. So, female civil servants may be a group of workers with specific features that lead them to be less motivated and make fewer efforts.

Finally, job amenities are very important when explaining workers' labour effort. In this way, efforts diminish if it is a routine, stressing, tiring, or shift job; whereas it increases when workers have flexible working hours, promotion prospects, stimulating workplaces, wellorganized jobs, there are good relations with the managing board, and workers know firm targets and may give opinions on their tasks.

Which economic policy recommendations come from this research? It seems that Public Administration workers show lower labour effort levels than private sector ones. Besides, it has been detected that labour effort is especially sensitive to job stability (in the case of civil servants) and to the climate of industrial relations. For this reason, if we want to raise effort levels in the public sector, we may focus on these variables. First, we may stimulate motivation among workers at the public sector by means of a wide variety of incentives (wage complements to differentiate productive workers from non-productive ones, new tasks, better and clear promotion prospects...). In the second place, when incentives are not enough, it will be necessary to set up certain control and monitoring mechanisms to avoid moral hazard problems that are very common in the Public Administration. Finally, taking into account labour effort sensitivity to those variables standing for labour relations climate, human resources management policies should be improved by making 
hierarchical communication easier, by giving workers their own voice and opinion and by improving workplace environment when possible.

\section{References}

Akerlof, G. A. (1982). "Labor contracts as partial gift exchange". Quarterly Journal of Economics, 97 (4), 543-569.

Borjas, G. J. (1979). "Job satisfaction, wages, and unions". The Journal of Human Resources, 14 (1), 21-40.

Brown, S., McNabb, R. and Taylor, K. (2004). "Efficiency wages and effort: A test of the shirking and fair wage explanations". Cardiff Business School. Cardiff University, Cardiff.

Canal, J. F. and Rodríguez, C. (2004). "Collective bargaining and withinfirm wage dispersion in Spain”. British Journal of Industrial Relations, 42 (3), 481-506.

Clark, K. and Tomlinson, M. (2001). "The determinants of work effort: evidence from employment in Britain Survey". The School of Economic Discussion Paper Series n. ${ }^{\circ}$ 0113, School of Economics. The University of Manchester, Manchester.

Clark, A. E., Masclet, D. and Villeval, M. C. (2010). "Effort and comparison income: Experimental and survey evidence". Industrial and Labor Relations Review, 63 (3), 407-426.

Currie, M. and Steedman, I. (1993). "Taking effort seriously". Metroeconomica, 44 (2), 134-145.

Fairris, D. and Alston, L. J. (1994). "Wages and the intensity of labor effort: Efficiency wages versus compensating payments". Southern Economic Journal, 61 (1), 149-160.

Ferrer-i-Carbonell, A. and Frijters, P. (2004). "How Important is Methodology for the Estimates of the Determinants of Happiness?" The Economic Journal, 114 (July), 641-659. 
Freeman, R. B. (1978). "Job satisfaction as an economic variable". American Economic Review, 68 (2), 135-141.

Goldsmith, A. H., Veum, J. R. and Darity, W. (2000). "Working hard for the money? Efficiency wages and worker effort". Journal of Economic Psychology, 21 (4), 351-385.

Green, F. and McIntosh, S. (1998). "Union power, cost of job loss, and workers' effort”. Industrial and Labor Relations Review, 51 (3), 363-383.

Jimeno, J. F. and Toharia, L. (1996). "Effort, absenteeism, and fixed term employment contracts". Revista Española de Economía, 13 (1), 105-119.

Mühlau, P. and Lindenberg, S. (2003). "Efficiency wages: Signals or incentives? An empirical study of the relationship between wage and commitment”. Journal of Management and Governance, 7 (4), 385-400.

Pfeiffer, C. (2011). "Risk aversion and sorting into public sector employment", German Economic Review, 12 (1), 89-99.

Rosen, S. (1986). "The theory of equalizing differences". In: O. Ashenfelter and R. Layard. (Eds.), Handbook of Labor Economics, Vol. 1. NorthHolland, Amsterdam, pp. 641-692.

Shapiro, C. and Stiglitz, J. E. (1984). "Equilibrium unemployment as a worker discipline device". American Economic Review, 74 (3), 433-444.

Solow, R. M. (1979). "Another possible source of wage stickiness". Journal of Macroeconomics, 1, 79-82.

Stiglitz, J. E. (1974). "Alternative theories of wage determination and unemployment in l.d.c.'s: The labor turnover model”. Quarterly Journal of Economics, 88 (2), 194-227.

Weiss, A. (1980). "Job queues and layoffs in labor markets with flexible wages". Journal of Political Economy, 88 (3), 526-538. 


\section{Appendix. Variable definitions and descriptive statistics}

\section{Table A1: Variable definitions}

\begin{tabular}{|c|c|}
\hline Labour effort & $\begin{array}{l}\text { Agreement with the statement: I am ready to work more than I should just for } \\
\text { the benefit of the firm or organization I am working for. The individual must } \\
\text { give an answer ranging in a scale from } 1 \text { (strongly disagree) to } 5 \text { (strongly } \\
\text { agree) }\end{array}$ \\
\hline $\begin{array}{l}\text { Logarithm of } \\
\text { hourly wage }\end{array}$ & $\begin{array}{l}\text { Logarithm of hourly wage. This variable is defined by thirteen intervals. } \\
\text { Extreme values of intervals are deflacted in order to compute real values. }\end{array}$ \\
\hline \multicolumn{2}{|l|}{ Worker features } \\
\hline Age & Age of the worker \\
\hline $\mathrm{Age}^{2}$ & Squared age \\
\hline $\begin{array}{l}\text { Primary } \\
\text { education or less }\end{array}$ & $\begin{array}{l}\text { Education dummy variable taking value } 1 \text { if the worker has primary studies } \\
\text { or less than primary estudies and } 0 \text { otherwise }\end{array}$ \\
\hline $\begin{array}{l}\text { Secondary } \\
\text { education }\end{array}$ & $\begin{array}{l}\text { Education dummy variable taking value } 1 \text { if the worker has secondary studies } \\
\text { (eight years) and } 0 \text { otherwise }\end{array}$ \\
\hline $\begin{array}{l}\text { Vocational } \\
\text { training-Level } 1\end{array}$ & $\begin{array}{l}\text { Education dummy variable taking value } 1 \text { if the worker has vocational } \\
\text { training (medium level) and } 0 \text { otherwise }\end{array}$ \\
\hline $\begin{array}{l}\text { Vocational } \\
\text { training-Level } 2\end{array}$ & $\begin{array}{l}\text { Education dummy variable taking value } 1 \text { if the worker has vocational } \\
\text { training (high level) and } 0 \text { otherwise }\end{array}$ \\
\hline $\begin{array}{l}\text { High school } \\
\text { degree }\end{array}$ & $\begin{array}{l}\text { Education dummy variable taking value } 1 \text { if the worker has a high school } \\
\text { degree and } 0 \text { otherwise }\end{array}$ \\
\hline $\begin{array}{l}\text { University } \\
\text { education- } \\
\text { Level } 1\end{array}$ & $\begin{array}{l}\text { Education dummy variable taking value } 1 \text { if the worker has university studies } \\
\text { (medium level degree-three years) and } 0 \text { otherwise }\end{array}$ \\
\hline $\begin{array}{l}\text { University } \\
\text { education- } \\
\text { Level } 2\end{array}$ & $\begin{array}{l}\text { Education dummy variable taking value } 1 \text { if the worker has university studies } \\
\text { (high level degree-four or five years) and } 0 \text { otherwise }\end{array}$ \\
\hline Doctorate & $\begin{array}{l}\text { Education dummy variable taking value } 1 \text { if the worker has doctorate- } \\
\text { postgraduate studies and } 0 \text { otherwise }\end{array}$ \\
\hline Other studies & $\begin{array}{l}\text { Education dummy variable taking value } 1 \text { if the worker has other types of } \\
\text { studies and } 0 \text { otherwise }\end{array}$ \\
\hline Single & Dummy variable taking value 1 if the worker is single and 0 otherwise \\
\hline Married & Dummy variable taking value 1 if the worker is married and 0 otherwise \\
\hline $\begin{array}{l}\text { Separated- } \\
\text { Divorced }\end{array}$ & $\begin{array}{l}\text { Dummy variable taking value } 1 \text { if the worker is separated/divorced and } 0 \\
\text { otherwise }\end{array}$ \\
\hline Widower & $\begin{array}{l}\text { Dummy variable taking value } 1 \text { if the worker is widow/widower and } 0 \\
\text { otherwise }\end{array}$ \\
\hline $\begin{array}{l}\text { Dependent } \\
\text { children }\end{array}$ & $\begin{array}{l}\text { Dummy variable taking value } 1 \text { if the worker has dependent children and } 0 \\
\text { otherwise }\end{array}$ \\
\hline Union affiliated & $\begin{array}{l}\text { Dummy variable taking value } 1 \text { if the worker is affiliated to any union and } 0 \\
\text { otherwise }\end{array}$ \\
\hline Born in Spain & $\begin{array}{l}\text { Dummy variable taking value } 1 \text { if the worker was born in Spain and } 0 \\
\text { otherwise }\end{array}$ \\
\hline Male & Dummy variable taking value 1 for men and 0 for women \\
\hline \multicolumn{2}{|l|}{ Job features } \\
\hline Civil servant & $\begin{array}{l}\text { Dummy variable taking value } 1 \text { if the worker is a civil servant (funcionario) } \\
\text { and } 0 \text { otherwise }\end{array}$ \\
\hline $\begin{array}{l}\text { Permanent } \\
\text { labour contract }\end{array}$ & $\begin{array}{l}\text { Dummy variable taking value } 1 \text { if the worker has a permanent contract either } \\
\text { in the Public Administration or in a firm (public or private) and } 0 \text { otherwise }\end{array}$ \\
\hline $\begin{array}{l}\text { Temporary } \\
\text { contract }\end{array}$ & $\begin{array}{l}\text { Dummy variable taking value } 1 \text { if the worker has a temporary contract either } \\
\text { in the Public Administration or in a firm (public or private) and } 0 \text { otherwise }\end{array}$ \\
\hline
\end{tabular}


Under-employed Dummy variable taking value 1 if the worker is underemployed (he has higher skill levels than those required by the job) and 0 otherwise

Routine job Dummy variable taking value 1 if the worker always do the same task and 0 otherwise

Stressing job Dummy variable taking value 1 if the job is always or frequently stressing and 0 otherwise

Risky job Dummy variable taking value 1 if the job is always or frequently risky and 0 otherwise

Tiring job Dummy variable taking value 1 if the worker comes back home always or frequently very tired and 0 otherwise

Shift job Dummy variable taking value 1 if the employee is a shift worker and 0 otherwise

Flexible working Dummy variable taking value 1 if the worker may always choose working hours hours or quite often and 0 otherwise

Promotion Dummy variable taking value 1 if the worker is quite or highly likely to be prospects promoted in the firm with his knowledge and 0 otherwise

Stimulating

environment Dummy variable taking value 1 if the workplace environment is very or highly stimulating and 0 otherwise

Good work Dummy variable taking value 1 if the worker is very or highly satisfied with organization job organization at the firm and 0 otherwise

Teamwork Dummy variable taking value 1 if the employee do his job in a teamwork environment (even only occasionally) and 0 otherwise

Good labour Dummy variable taking value 1 if labour-management relations are very good relations or quite good and 0 otherwise

Worker knows Dummy variable taking value 1 if the worker knows well or quite well firm firm targets targets and 0 otherwise

Worker gives Dummy variable taking value 1 if the worker can always or many times give opinions opinions about his job and 0 otherwise

Collective Dummy variable taking value 1 if the worker is covered by a collective agreement agreement and 0 otherwise

Firm/Organization features

Public Dummy variable taking value 1 if the employee is a wage earner in the Civil Administration Service (Public Administration) and 0 otherwise

Public firm Dummy variable taking value 1 if the employee is a wage earner in a public firm or a public financial institution and 0 otherwise

Other public Dummy variable taking value 1 if the employee is a wage earner in other organizations public organization and 0 otherwise

Private firm Dummy variable taking value 1 if the employee is a wage earner in a private firm and 0 otherwise

Firm/Org. size Ten firm/organization size dummy variables (from 1 to above 1,000 workers) variables

Control variables: region (17 variables), occupation (9 variables) and year(6 variables) 
24 Rodríguez-Gutiérrez\&Canal-Dguez. /Revista de Economía Laboral 9 (2012), 1-27

Table A2: Descriptive statistics (total sample and men and women subsamples)

\begin{tabular}{|c|c|c|c|c|c|c|}
\hline & \multicolumn{2}{|c|}{ Total } & \multicolumn{2}{|c|}{ Men } & \multicolumn{2}{|c|}{ Women } \\
\hline & Mean & St. Dev. & Mean & St. Dev. & Mean & St. Dev. \\
\hline Labour effort & 2.948 & 1.272 & 3.011 & 1.252 & 2.840 & 1.297 \\
\hline \multicolumn{7}{|l|}{ Worker features } \\
\hline Age & 38.427 & 10.740 & 39.261 & 10.920 & 36.985 & 10.263 \\
\hline $\mathrm{Age}^{2}$ & $1,591.9$ & 865.4 & $1,660.6$ & 890.8 & $1,473.1$ & 806.1 \\
\hline Primary education or less & 0.185 & 0.388 & 0.223 & 0.416 & 0.119 & 0.324 \\
\hline Secondary education & 0.239 & 0.427 & 0.264 & 0.441 & 0.197 & 0.398 \\
\hline Vocational training-Level 1 & 0.091 & 0.287 & 0.092 & 0.289 & 0.088 & 0.284 \\
\hline Vocational training-Level 2 & 0.104 & 0.305 & 0.102 & 0.302 & 0.107 & 0.309 \\
\hline High school degree & 0.129 & 0.336 & 0.117 & 0.321 & 0.152 & 0.359 \\
\hline University education-Level 1 & 0.123 & 0.328 & 0.088 & 0.283 & 0.183 & 0.387 \\
\hline University education-Level 2 & 0.100 & 0.299 & 0.088 & 0.284 & 0.119 & 0.324 \\
\hline Doctorate & 0.022 & 0.145 & 0.019 & 0.135 & 0.027 & 0.161 \\
\hline Other studies & 0.008 & 0.089 & 0.008 & 0.088 & 0.009 & 0.092 \\
\hline Single & 0.338 & 0.473 & 0.306 & 0.461 & 0.395 & 0.489 \\
\hline Married & 0.595 & 0.491 & 0.661 & 0.474 & 0.482 & 0.500 \\
\hline Separated-Divorced & 0.053 & 0.223 & 0.028 & 0.166 & 0.095 & 0.293 \\
\hline Widower & 0.014 & 0.116 & 0.005 & 0.072 & 0.028 & 0.165 \\
\hline Dependent children & 0.535 & 0.499 & 0.557 & 0.497 & 0.496 & 0.500 \\
\hline Union affiliated & 0.226 & 0.418 & 0.244 & 0.430 & 0.193 & 0.395 \\
\hline Born in Spain & 0.956 & 0.204 & 0.956 & 0.206 & 0.958 & 0.201 \\
\hline Male & 0.634 & 0.482 & 1 & 0 & 0 & 0 \\
\hline \multicolumn{7}{|l|}{ Job features } \\
\hline Civil servant & 0.132 & 0.339 & 0.114 & 0.317 & 0.165 & 0.371 \\
\hline Permanent labour contract & 0.616 & 0.486 & 0.646 & 0.478 & 0.564 & 0.496 \\
\hline Temporary contract & 0.252 & 0.434 & 0.241 & 0.427 & 0.272 & 0.445 \\
\hline Underemployed & 0.187 & 0.390 & 0.168 & 0.374 & 0.219 & 0.414 \\
\hline Routine job & 0.772 & 0.419 & 0.749 & 0.434 & 0.813 & 0.390 \\
\hline Stressing job & 0.334 & 0.472 & 0.329 & 0.470 & 0.343 & 0.475 \\
\hline Risky job & 0.153 & 0.360 & 0.203 & 0.403 & 0.064 & 0.246 \\
\hline Tiring job & 0.472 & 0.499 & 0.463 & 0.499 & 0.489 & 0.500 \\
\hline Shift job & 0.216 & 0.412 & 0.222 & 0.416 & 0.207 & 0.405 \\
\hline Flexible working hours & 0.138 & 0.345 & 0.151 & 0.358 & 0.115 & 0.320 \\
\hline Promotion prospects & 0.214 & 0.410 & 0.224 & 0.417 & 0.197 & 0.398 \\
\hline Stimulating environment & 0.479 & 0.500 & 0.469 & 0.499 & 0.495 & 0.500 \\
\hline Good work organization & 0.677 & 0.468 & 0.680 & 0.467 & 0.673 & 0.469 \\
\hline Teamwork & 0.702 & 0.458 & 0.726 & 0.446 & 0.660 & 0.474 \\
\hline Good labour relations & 0.647 & 0.478 & 0.641 & 0.480 & 0.658 & 0.475 \\
\hline
\end{tabular}


Workers' Effort, Contract Type and Firm Ownership

\begin{tabular}{lllllll} 
Worker knows firm targets & 0.743 & 0.437 & 0.741 & 0.438 & 0.746 & 0.435 \\
Worker gives opinions & 0.586 & 0.493 & 0.575 & 0.494 & 0.604 & 0.489 \\
Collective agreement & 0.801 & 0.399 & 0.809 & 0.393 & 0.787 & 0.409 \\
Firm/Organization features & & & & & & \\
Public Administration & 0.211 & 0.408 & 0.169 & 0.375 & 0.283 & 0.450 \\
Public firm & 0.022 & 0.147 & 0.023 & 0.151 & 0.020 & 0.140 \\
Other public organizations & 0.016 & 0.125 & 0.014 & 0.116 & 0.020 & 0.140 \\
Private firm & 0.751 & 0.432 & 0.794 & 0.404 & 0.677 & 0.468 \\
Firm/Org. size 1 & 0.018 & 0.132 & 0.010 & 0.102 & 0.031 & 0.172 \\
Firm/Org. size 2-9 & 0.209 & 0.406 & 0.207 & 0.405 & 0.211 & 0.408 \\
Firm/Org. size 10-25 & 0.170 & 0.376 & 0.177 & 0.381 & 0.159 & 0.366 \\
Firm/Org. size 26-49 & 0.110 & 0.313 & 0.116 & 0.320 & 0.101 & 0.301 \\
Firm/Org. size 50-99 & 0.090 & 0.287 & 0.092 & 0.290 & 0.087 & 0.282 \\
Firm/Org. size 100-249 & 0.090 & 0.286 & 0.091 & 0.288 & 0.087 & 0.281 \\
Firm/Org. size 250-499 & 0.051 & 0.219 & 0.053 & 0.224 & 0.046 & 0.210 \\
Firm/Org. size 500-999 & 0.041 & 0.199 & 0.042 & 0.201 & 0.040 & 0.195 \\
Firm/Org. size $\geq 1000$ & 0.151 & 0.358 & 0.150 & 0.358 & 0.152 & 0.359 \\
Firm/Org. size is not declared & 0.070 & 0.255 & 0.061 & 0.238 & 0.086 & 0.281 \\
\hline No. of observations & \multicolumn{7}{c}{15,252} & 9,666 & & 5,586 \\
\hline
\end{tabular}


Table A3: Descriptive statistics (total sample and men and women subsamples excluding civil servants)

\begin{tabular}{|c|c|c|c|c|c|c|}
\hline & \multicolumn{2}{|c|}{ Total } & \multicolumn{2}{|c|}{ Men } & \multicolumn{2}{|c|}{ Women } \\
\hline & Mean & St. Dev. & Mean & St. Dev. & Mean & St. Dev. \\
\hline Labour effort & 2.974 & 1.271 & 3.029 & 1.252 & 2.872 & 1.299 \\
\hline \multicolumn{7}{|l|}{ Worker features } \\
\hline Age & 37.668 & 10.744 & 38.642 & 10.915 & 35.879 & 10.183 \\
\hline $\mathrm{Age}^{2}$ & 1534.2 & 857.1 & 1612.3 & 882.0 & 1391.0 & 789.5 \\
\hline Primary education or less & 0.205 & 0.404 & 0.242 & 0.428 & 0.138 & 0.345 \\
\hline Secondary education & 0.263 & 0.440 & 0.283 & 0.450 & 0.227 & 0.419 \\
\hline Vocational training-Level 1 & 0.097 & 0.297 & 0.099 & 0.298 & 0.095 & 0.294 \\
\hline Vocational training-Level 2 & 0.109 & 0.312 & 0.107 & 0.309 & 0.114 & 0.318 \\
\hline High school degree & 0.121 & 0.326 & 0.107 & 0.309 & 0.146 & 0.354 \\
\hline University education-Level 1 & 0.102 & 0.303 & 0.076 & 0.264 & 0.151 & 0.358 \\
\hline University education-Level 2 & 0.078 & 0.269 & 0.068 & 0.251 & 0.098 & 0.298 \\
\hline Doctorate & 0.016 & 0.125 & 0.013 & 0.114 & 0.021 & 0.143 \\
\hline Other studies & 0.008 & 0.090 & 0.008 & 0.088 & 0.009 & 0.093 \\
\hline Single & 0.357 & 0.479 & 0.323 & 0.468 & 0.418 & 0.493 \\
\hline Married & 0.581 & 0.493 & 0.645 & 0.479 & 0.463 & 0.499 \\
\hline Separated-Divorced & 0.050 & 0.219 & 0.027 & 0.162 & 0.093 & 0.291 \\
\hline Widower & 0.012 & 0.109 & 0.005 & 0.070 & 0.025 & 0.156 \\
\hline Dependent children & 0.518 & 0.500 & 0.543 & 0.498 & 0.472 & 0.499 \\
\hline Union affiliated & 0.211 & 0.408 & 0.231 & 0.421 & 0.173 & 0.379 \\
\hline Born in Spain & 0.953 & 0.213 & 0.952 & 0.213 & 0.953 & 0.212 \\
\hline Male & 0.647 & 0.478 & 1 & 0 & 0 & 0 \\
\hline \multicolumn{7}{|l|}{ Job features } \\
\hline Permanent labour contract & 0.710 & 0.454 & 0.729 & 0.445 & 0.675 & 0.468 \\
\hline Temporary contract & 0.290 & 0.454 & 0.271 & 0.445 & 0.325 & 0.468 \\
\hline Underemployed & 0.192 & 0.394 & 0.170 & 0.375 & 0.233 & 0.423 \\
\hline Routine job & 0.776 & 0.417 & 0.751 & 0.433 & 0.824 & 0.381 \\
\hline Stressing job & 0.323 & 0.468 & 0.321 & 0.467 & 0.325 & 0.468 \\
\hline Risky job & 0.157 & 0.364 & 0.207 & 0.405 & 0.064 & 0.245 \\
\hline Tiring job & 0.492 & 0.500 & 0.485 & 0.500 & 0.504 & 0.500 \\
\hline Shift job & 0.216 & 0.412 & 0.217 & 0.412 & 0.216 & 0.412 \\
\hline Flexible working hours & 0.136 & 0.343 & 0.148 & 0.355 & 0.114 & 0.318 \\
\hline Promotion prospects & 0.207 & 0.405 & 0.218 & 0.413 & 0.186 & 0.389 \\
\hline Stimulating environment & 0.481 & 0.500 & 0.472 & 0.499 & 0.498 & 0.500 \\
\hline Good work organization & 0.684 & 0.465 & 0.686 & 0.464 & 0.680 & 0.467 \\
\hline Teamwork & 0.692 & 0.462 & 0.719 & 0.450 & 0.644 & 0.479 \\
\hline Good labour relations & 0.644 & 0.479 & 0.641 & 0.480 & 0.651 & 0.477 \\
\hline Worker knows firm targets & 0.724 & 0.447 & 0.725 & 0.447 & 0.722 & 0.448 \\
\hline
\end{tabular}




\begin{tabular}{lllllll} 
Worker gives opinions & 0.570 & 0.495 & 0.563 & 0.496 & 0.582 & 0.493 \\
Collective agreement & 0.779 & 0.415 & 0.793 & 0.405 & 0.755 & 0.430 \\
Firm/Organization features & & & & & & \\
Public Administration & 0.104 & 0.305 & 0.074 & 0.262 & 0.159 & 0.365 \\
Public firm & 0.019 & 0.137 & 0.020 & 0.141 & 0.017 & 0.128 \\
Other public organizations & 0.011 & 0.104 & 0.009 & 0.096 & 0.014 & 0.117 \\
Private firm & 0.866 & 0.341 & 0.896 & 0.305 & 0.811 & 0.392 \\
Firm/Org. size 1 & 0.020 & 0.141 & 0.012 & 0.107 & 0.036 & 0.187 \\
Firm/Org. size 2-9 & 0.234 & 0.423 & 0.228 & 0.420 & 0.245 & 0.430 \\
Firm/Org. size 10-25 & 0.179 & 0.384 & 0.187 & 0.390 & 0.166 & 0.372 \\
Firm/Org. size 26-49 & 0.112 & 0.315 & 0.118 & 0.322 & 0.100 & 0.300 \\
Firm/Org. size 50-99 & 0.090 & 0.287 & 0.093 & 0.290 & 0.086 & 0.281 \\
Firm/Org. size 100-249 & 0.092 & 0.289 & 0.093 & 0.290 & 0.090 & 0.286 \\
Firm/Org. size 250-499 & 0.050 & 0.219 & 0.053 & 0.224 & 0.046 & 0.209 \\
Firm/Org. size 500-999 & 0.039 & 0.194 & 0.040 & 0.196 & 0.038 & 0.191 \\
Firm/Org. size $\geq 1000$ & 0.120 & 0.325 & 0.123 & 0.329 & 0.115 & 0.319 \\
Firm/Org. size is not declared & 0.063 & 0.242 & 0.054 & 0.225 & 0.079 & 0.270 \\
\hline No. of observations & & 13,223 & & 8,568 & & 4,665 \\
\hline
\end{tabular}

